\title{
Changing policy
}

Population Council

Follow this and additional works at: https://knowledgecommons.popcouncil.org/ series_newsletters_momentum How does access to this work benefit you? Let us know!

\section{Recommended Citation}

"Changing policy," Momentum newsletter. New York: Population Council, 2011. 


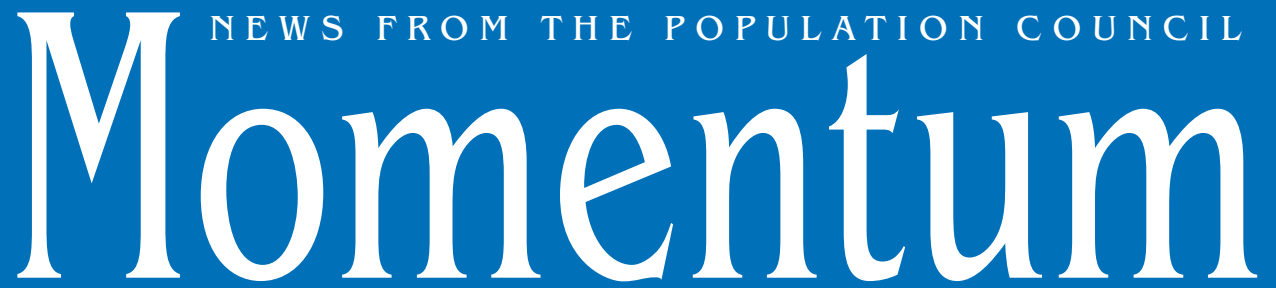

$\begin{array}{llllll}\text { J U N E } & 2 & 0 & 1 & 1\end{array}$

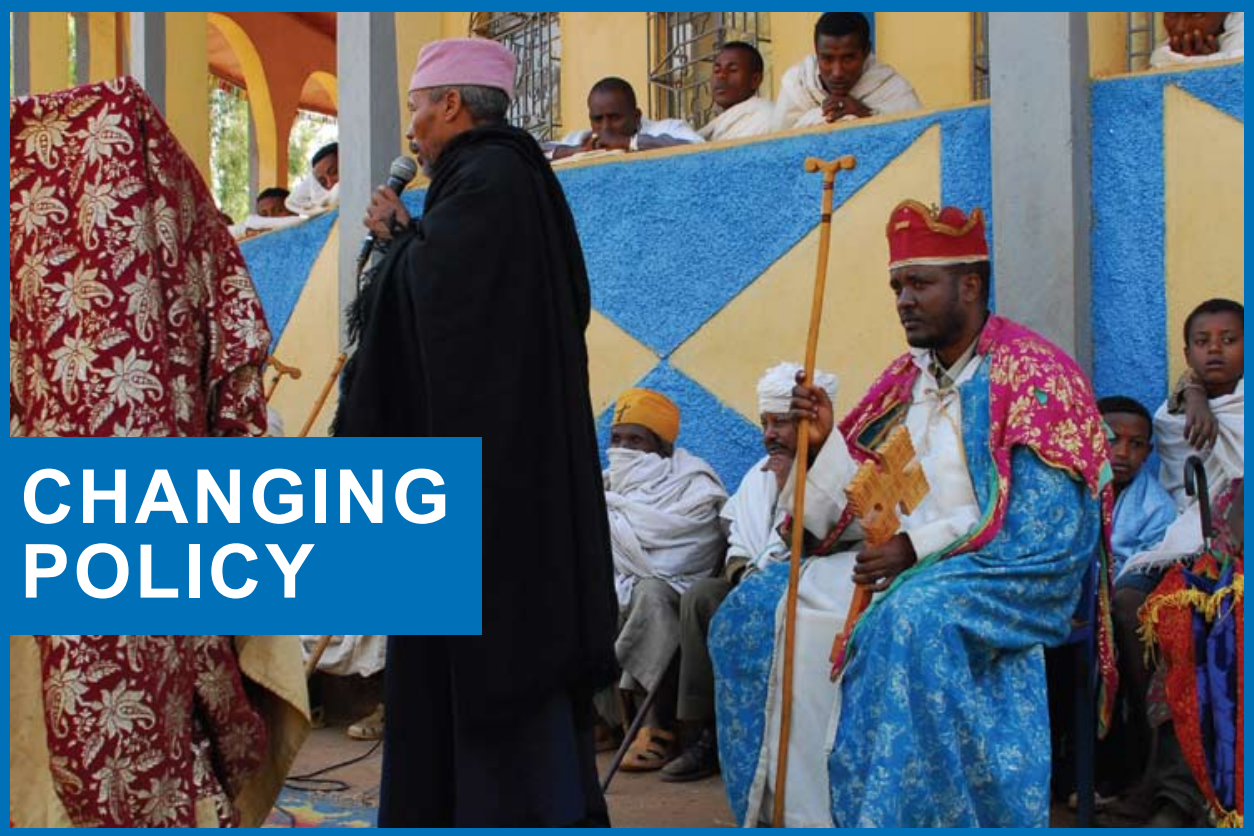

The Council is improving public IN THIS ISSUE:

POPULATION COUNCIL PRESIDENT health through its work with the Ethiopian Orthodox Church.

DISCUSSES COUNCIL'S IMPACT ON POLICY

STRENGTHENING EC POLICIES IN BANGLADESH

CHANGING HOW POLICYMAKERS THINK ABOUT EARLY MARRIAGE

TARGETING GLOBAL INVESTMENTS IN HIV

DEVELOPING THE POTENTIAL OF INDIA'S YOUTH

STRENGTHENING POLICIES FOR SEXUAL VIOLENCE VICTIMS

PROTECTING MIGRANTS FROM HIV

PROFILES: DR. TEKLE-AB MEKBIB, COUNCIL RESEARCHER, AND

DR. WAFAA EL-SADR, COUNCIL TRUSTEE 

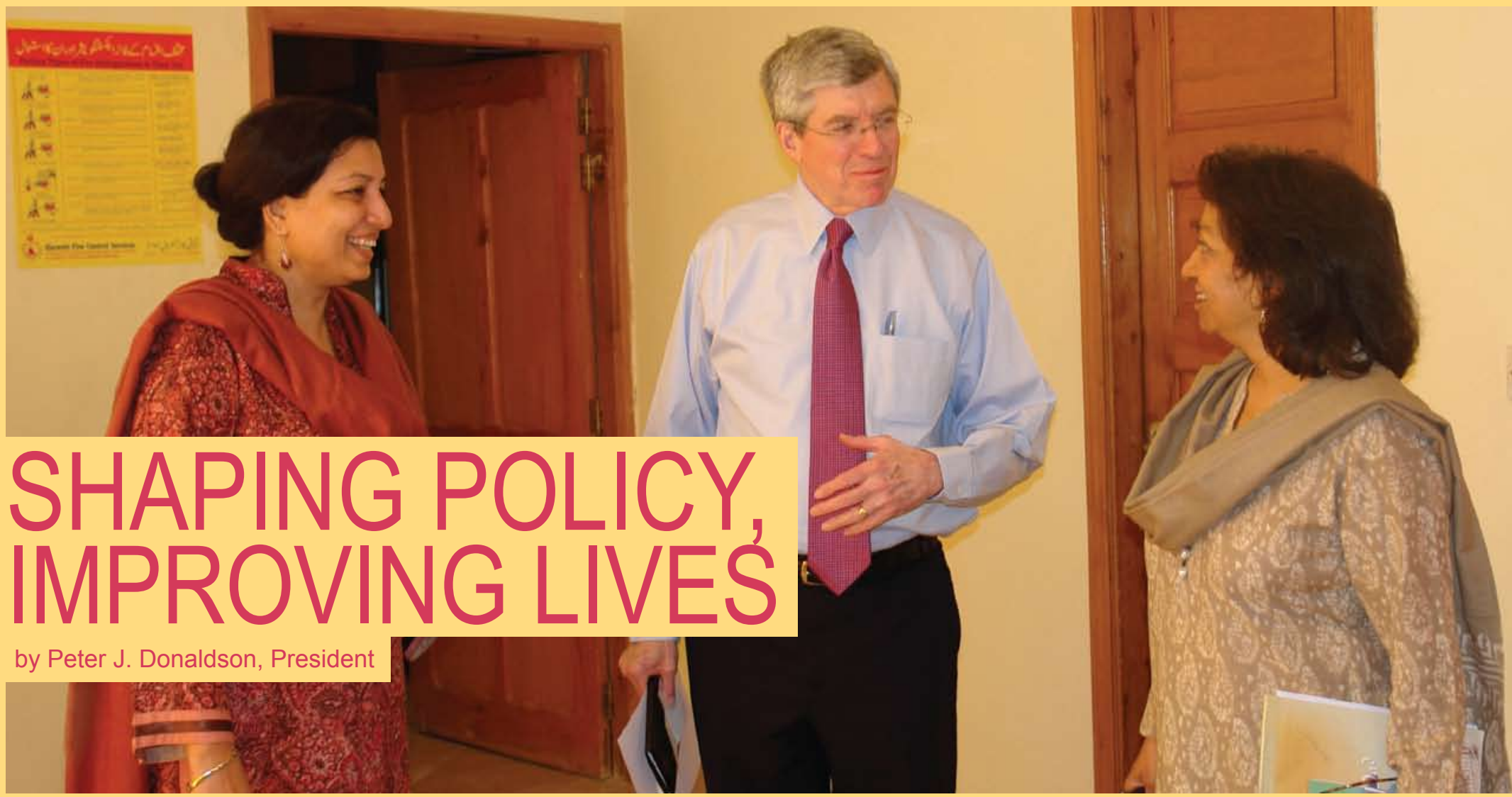

In Islamabad, Pakistan Population Council president Peter J. Donaldson meets with Seemin Ashfaq, program manager, and Zeba Sathar, country director. Since the Council began to work in Pakistan in the late 1950s, we have been collaborating with the government to develop national policies to address complex population and reproductive health issues.

At the Population Council, we improve lives by conducting research that influences policy and provides practical solutions to pressing health and development concerns. We collaborate with key stakeholders at the country level and internationally to:

- $\quad$ identify public health and development problems;

- conduct research on these challenges;

- design, implement, and evaluate health and development program interventions; and

- $\quad$ scale up successful interventions and help them become sustainable.

In this way, Council research catalyzes large-scale social change that improves the lives of vulnerable people around the world.
In Bangladesh, for example, we responded to a request from the government to evaluate whether emergency contraception (EC) could reduce unplanned pregnancies and abortion (page 2). Using evidence and strategies generated by the Council, the Bangladesh government introduced EC into the national family planning program.

This issue of Momentum illustrates ways the Council has shaped and improved policy in other countries as well, for example:
- We have shed light on the harmful practice of child marriage and influenced policy to prevent it (page 4),

- Policymakers and donors have acted on our recommendations about allocating scarce HIV funds (page 6),

- Policymakers in developing countries have used our nationally representative surveys of youth to change programs (page 8),

- Our evaluations have strengthened policies and programs in Africa to help sexual violence victims get immediate medical and psychological care (page 10), and

- We have guided government strategies on migration and HIV in India (page 12).
Additionally, you will meet Tekle-Ab Mekbib, a Population Council public health physician based in Addis Ababa, Ethiopia. He describes how his career evolved from providing day-to-day medical care to influencing health policy throughout Ethiopia. You will also read why Dr. Wafaa El-Sadr gives her time as a Council trustee and contributes financially as well (page 14).

Your partnership enables us to provide the necessary evidence for effective policies, programs, and technologies that improve lives worldwide. 


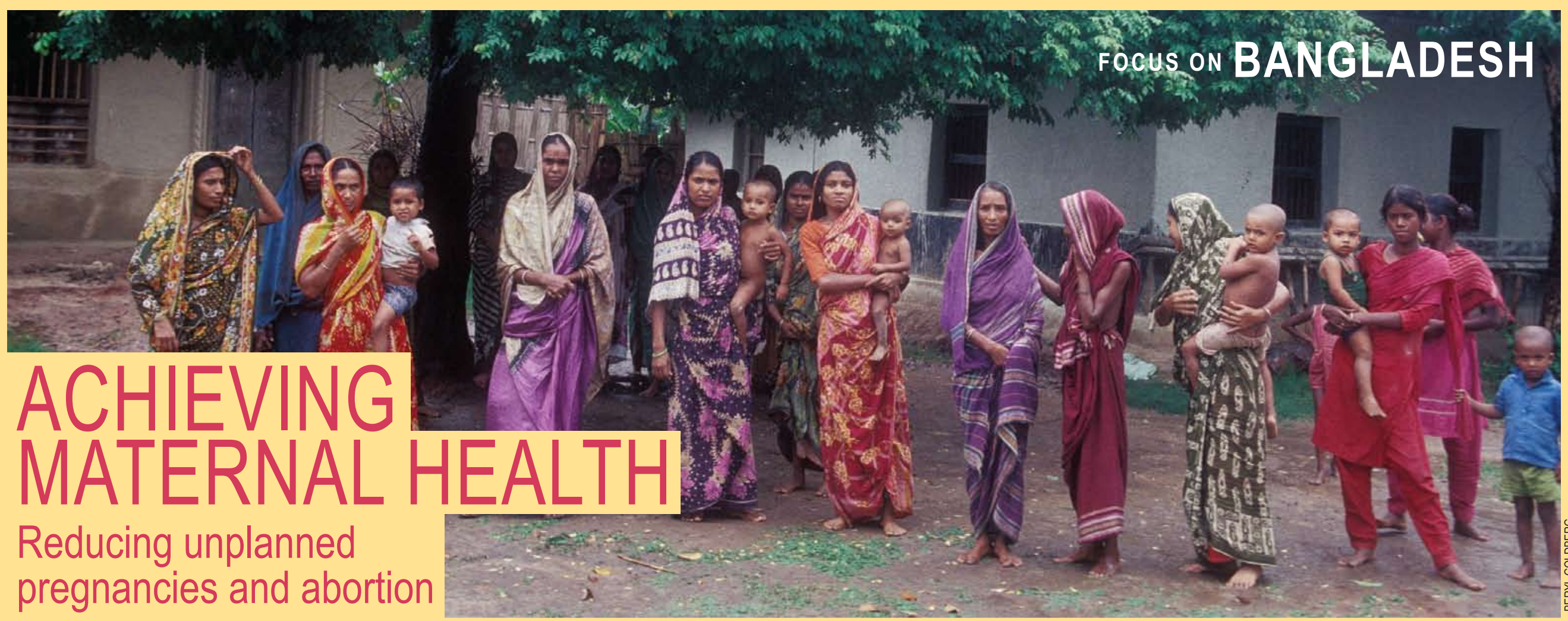

In 2001, the Ministry of Health and Family Welfare in

Bangladesh identified emergency contraception

(EC) - which prevents unwanted pregnancy within 120 hours of unprotected sex-as a back-up method that could reduce unplanned pregnancies and abortions. Working with the Ministry and other partners, the Population Council provided the evidence for introducing EC into the national family planning program. Following policy changes based on that evidence the Council then designed and helped guide the nationwide introduction of EC
1. IDENTIFYAND UNDERSTAND THE PROBLEM

The Council assessed the feasibility of introducing EC: Would women accept and properly use EC? Could service providers be trained to provide information and counsel women?
2. DEVELOP AND INTRODUCE EC DELIVERY

The Council used data to develop training materials counseling guidelines, and educational aids for training a small number of providers in delivering EC services.
3. TEST AND EVALUATE EC DELIVERY

The Council evaluated the introduction of EC by interviewing providers after training and assessing women's knowledge and use of EC after unprotected intercourse.
4. USE EVIDENCE TO INFLUENCE POLICIES

The Council engaged the Ministry and partners, communicating findings and progress through workshops, printed materials, and the media. The Ministry approved the introduction of EC in the national family planning program.
5. PROVIDE GUIDANCE TO SUPPORT EXPANSION

The Council helped train 3,000 trainers who, in turn, educated about 42,000 grass-roots and community-based providers. Women throughout Bangladesh gained access to EC through these providers.

SERVICE PROVIDERS WHO FAVORED THE INTRODUCTION OF EC

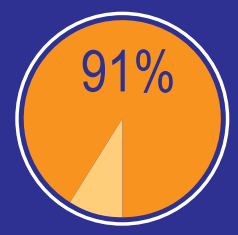

SERVICE PROVIDERS WHO UNDERSTOOD AND COULD EXPLAIN HOW TO USE EC

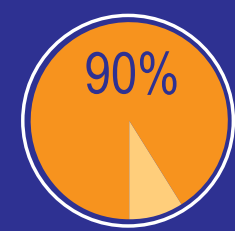

WOMEN WHO ADOPTED A CONTRACEPTIVE METHOD FOR
THE FIRST TIME AFTER USING EC

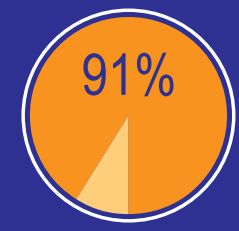

ESTIMATED REDUCTION IN ABORTION BY

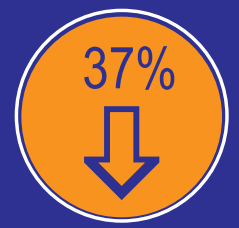

NUMBER OF TRAINERS AND PROVIDERS EDUCATED TO DELIVER EC

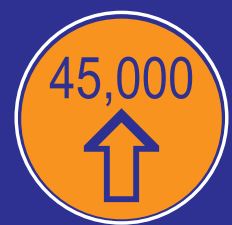




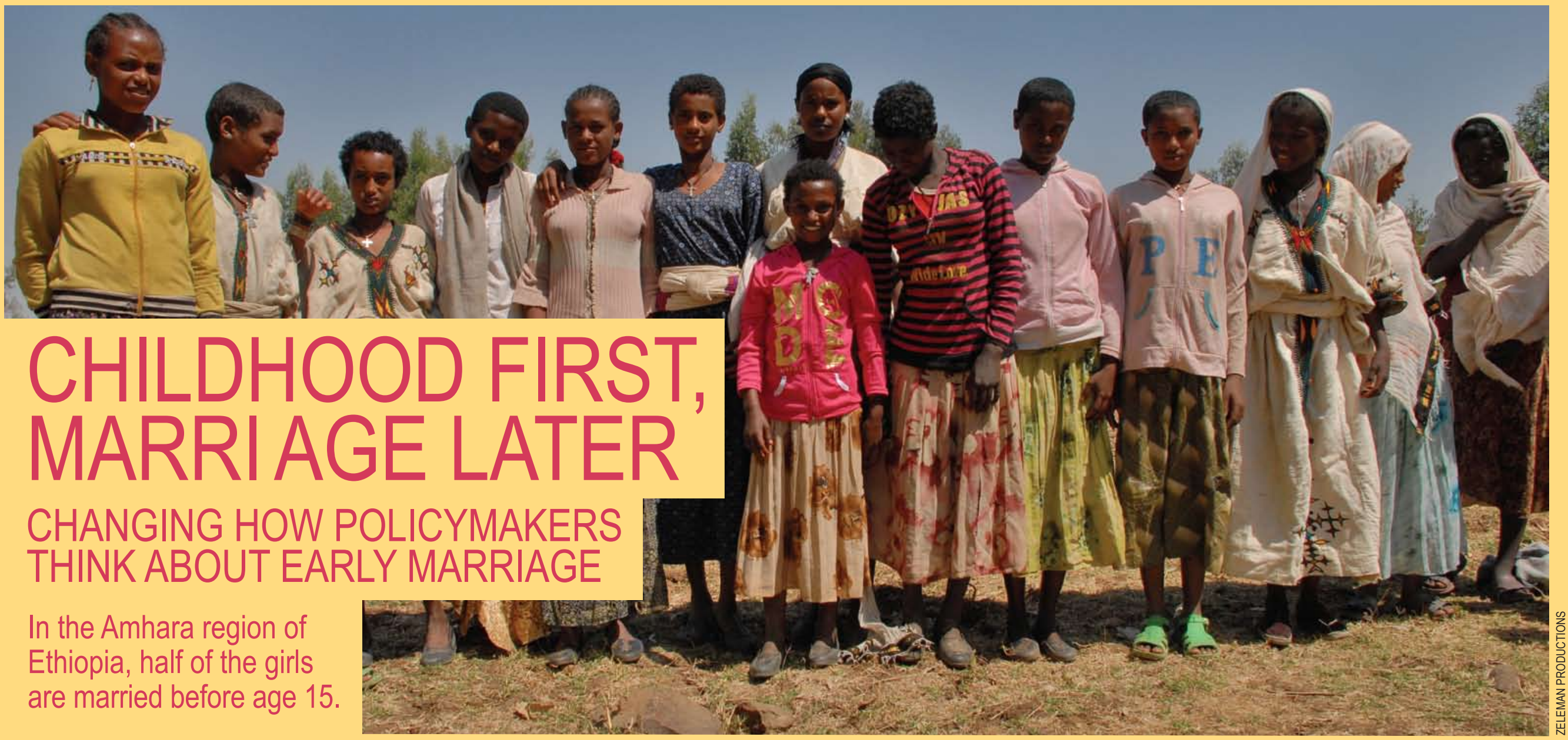

THE PROBLEM When a girl is married in her early teens or younger, her opportunities to go to school,

become literate, and form friendships vanish. She is at high risk for unwanted marital sex, risky pregnancies, and, in some countries, HIV. In Ethiopia, while the legal age of marriage is 18 , half of the girls in the Amhara region, one of the poorest areas of the country, are married before age $15 ; 80$ percent are married by age 18 . The practice of early marriage is strongly influenced by the societal requirement of creating alliances between families or enhancing a family's reputation. Clearly, policies must do much more than legislate a marriage age.
THE PROGRESS The Population Council collaborates with the local government to conduct the Berhane Hewan ("A Light for Eve") program, one of the first evaluated programs shown to increase the age of marriage for girls in sub-Saharan Africa. The program focuses on the drivers of early marriage by providing economic incentives to families and raising awareness of the harmful effects of early marriage. It seeks to alleviate young brides' social isolation, give them opportunities for education, and address reproductive health needs. The program provides support for girls to stay in school and offers informal instruction in reading, writing, arithmetic, and reproductive health. Berhane Hewan also helps girls learn social skills, develop selfconfidence, and make friends. Two years after implementation, the evaluation of communities offering the program showed an increase in friendship networks, school attendance, use of contraception, and a delay of marriage.

THE IMPACT The Council's approach to early marriage has changed international policy discussions. By focusing on the needs of girls and addressing the drivers of early marriage, rather than merely educating communities on the dangers of the practice, we have helped redefine early marriage as more than a reproductive health issue. Early marriage is now recognized as a key risk factor related to the health and well-being of populations in the developing world. Our approach has been adopted by UNFPA and UNICEF. The

Council has begun a five-year program that will test different combinations of the elements of the Berhane Hewan program in early marriage interventions in Kenya, Tanzania, and Uganda.

DONORS AND PARTNERS Ethiopian Ministry of Youth and Sports, UK Department for International Development, United Nations Population Fund, Nike Foundation, United Nations Foundation 
TARGETING GLOBAL INVESTMENTS TO SAVE MORE LIVES

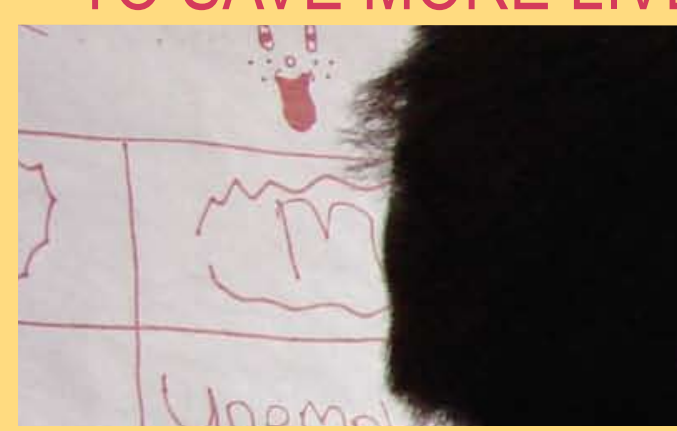

The HIV and AIDS epidemic

consumes almost a quarter of

total global health assistance,

yet only 5 percent of deaths

in the developing world are

caused by the disease.

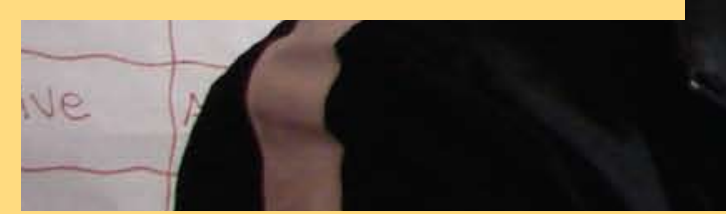

THE PROBLEM The costs for universal antiretroviral treatment of AIDS patients in the developing world are rapidly rising and will be unsustainable in the long run. Two to three new HIV infections occur for every new patient put on treatment. If AIDS treatment funding is allowed to grow without allocating more to HIV-prevention measures, the cost could consume half of the US foreign aid budget by 2016 and all of it by 2024. Funds are needed for HIVprevention programs and for other diseases that are responsible for the majority of preventable deaths.
THE PROGRESS Population Council Distinguished Scholar John Bongaarts is a leading advocate for changing current resource allocations for global health aid and investing in cost-effective solutions that save more lives. In a recent article in the journal Science, Bongaarts and co-author Mead Over suggest that policymakers continue their obligation to treat current AIDS patients while limiting enrollment of new patients and instead focus on cost-effective HIV-prevention programs such as male circumcision, reducing the number of people who have sex with multiple partners, and prevention of mother-to-child transmission. Investing in HIV-prevention efforts would not only help contain the spread of HIV, but also free up resources for family planning, malaria, tuberculosis, and child immunization.

THE IMPACT Bongaarts and the Council are part of an international movement that is changing the way policymakers and the health community think about how global health funds should be allocated. Targeted investments in proven HIV-prevention strategies are increasingly viewed as the best way to manage the spread of the disease. The Obama Administration announced that "preventing new infections represents the only long-term, sustainable way to turn the tide against HIVIAIDS." In addition, PEPFAR, the US government's signature HIV and AIDS program, is now funding more integrated programs that enable health care workers to treat more diseases, not just HIV and AIDS. Other international agencies, including the World Bank, are poised to follow this funding approach. 


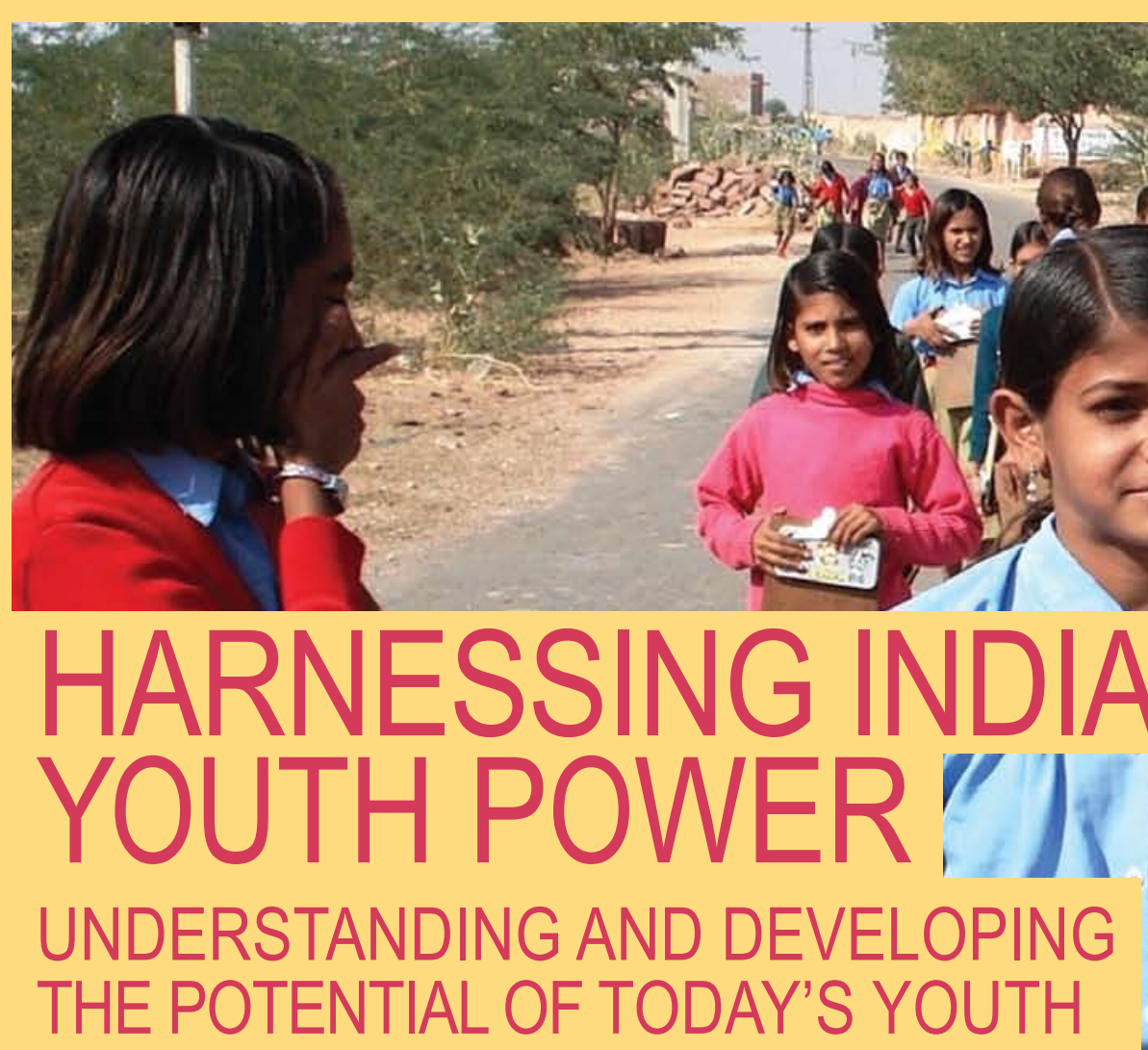

Disparities between the education of young men and women persist, and knowledge of reproductive health and HIV and AIDS is poor.

THE PROBLEM There are 354 million young people aged 10-24 years in India, representing almost one-third of the country's population. More information about these young people is critical to form policies that effectively promote the education, health, and employment of this new generation of Indians.

THE PROGRESS The Council, in collaboration with the International Institute for Population Sciences in India, conducted a landmark survey that covered important aspects of young people's lives: education and work, romance and sex, marriage, domestic violence, voting behavior, gender roles, and mental health issues. The study covered urban and rural areas of six states, representing about 40 percent of India's population. The survey found that India's youth, especially young women, face substantial challenges. Marriage occurs before age 18 for almost half of young women, and as a result, many girls bear children before they are prepared for motherhood. Premarital sex occurs among about one in seven young men and one in 20 young women. When it happens, it is largely unsafe and uninformed. For many young women, it is unwanted. Almost three-quarters of women are not permitted to make independent decisions regarding the choice of friends, spending money, or purchasing clothes for themselves, and one-quarter who were married had no say in the choice of husband.

THE IMPACT The survey results have provided politicians, government officials, and NGO leaders with data to identify the needs of youth and improve their health and development prospects.
The findings are "deeply informative and thought provoking," said Amartya Sen, Nobel Prize-winning economist and former Population Council trustee. The study "can serve as the basis of a necessary understanding of the lives of young people in India."

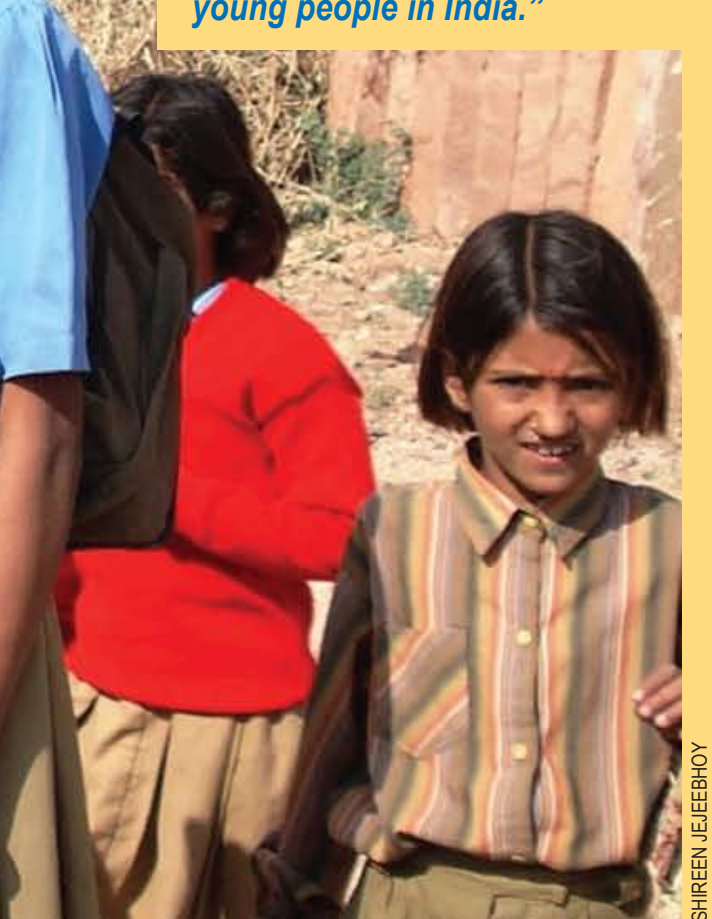

National and state governments are reviewing the impact of their current policies on youth populations and changing policies based on this new information. As the Minister of Health and Family Welfare declared, "we will take a closer look at the findings of this study and try to make mid-course corrections in programs for youth where required."

DONORS AND PARTNERS International Institute for Population Sciences, Mumbai; The John D. and Catherine T. MacArthur Foundation; The David and Lucile Packard Foundation 
The Council supports a network to improve comprehensive care POLICIES IN AFRICA FOR SEXUAL VIOLENCE VICTIMS

\section{Sexual violence endangers} girls' and women's physical and psychological wellbeing, exposes them to unwanted pregnancy and STIs, and perpetuates female subordination.

THE PROBLEM It is estimated that one in three women worldwide experiences sexual or gender-based violence (SGBV) in her lifetime. In many African communities, the subordinate status of women heightens their vulnerability to SGBV, from intimate partner violence and rape to female genital mutilation/ cutting. Victims of SGBV lack access to treatment, care, or support. Responding to victims remains a low priority for many policymakers, partly because of the lack of evidence of how best to meet their medical, psychological, and social needs. As a result, the capacity of the medical, legal, and judicial sectors to deliver services to victims remains low or non-existent.

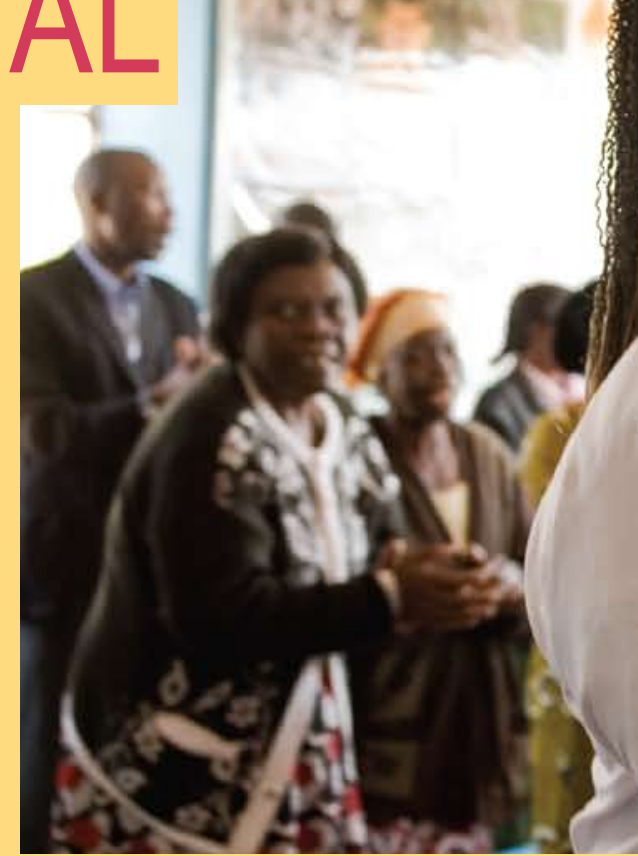

THE PROGRESS The Council supports a network throughout Africa, joining together ministries of health and justice, police forces, legal advocates, and civil society activists to improve the provision of comprehensive care for SGBV victims. The network members are providers of medical treatment, psychosocial support, police procedures, and legal assistance and other services. Having conducted an extensive review of models for SGBV management in Africa, the Council supports network members so that they can pilot and document best practices. Council staff have developed a comprehensive SGBV response model that meets the needs of both adult and child victims and can be readily adapted in different countries. Following this model, hospitals in Malawi reported an increased provision of post-exposure HIV prophylaxis to victims from 43 percent to 95 percent to reduce the likelihood of being infected with HIV.

THE IMPACT The Council's research has been used by African policymakers to develop strategies that address SGBV. Through regiona meetings facilitated by the Council, partners have developed and tested innovative strategies for engaging traditional leaders in preventing SGBV. In South Africa, the Council is supporting the nationwide scale-up of Post Exposure Prophylaxis (PEP). for sexual violence victims. Being part of an international network has allowed members to identify and share best practices and learn from others' experiences. 


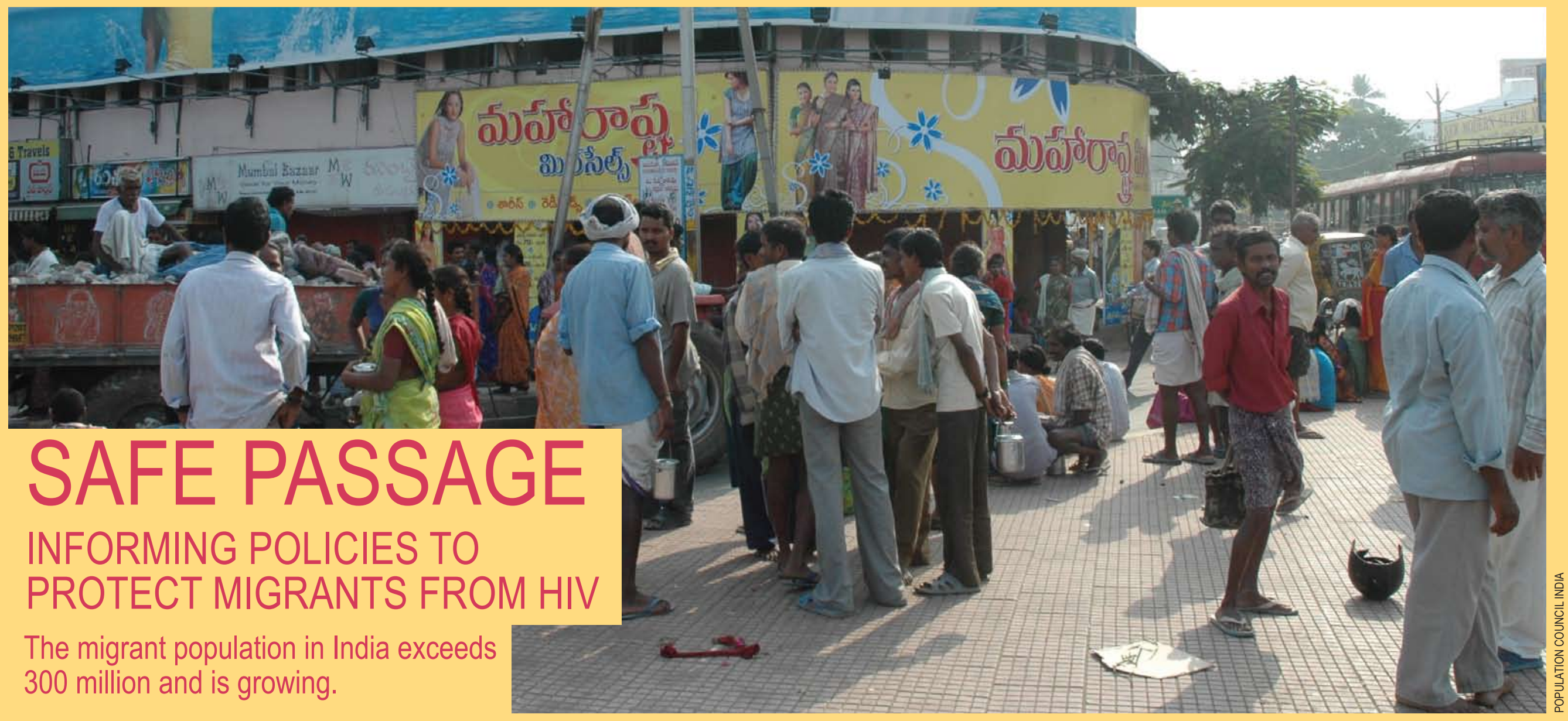

THE PROBLEM In India, the number of new annual HIV infections declined by more than 50 percent between 2000 and 2010. Yet some states with low HIV prevalence have shown an increase in the number of new infections. Coincidentally, these states also have high out-migration, mostly due to poverty, lack of economic opportunities, and high illiteracy. Migration may have contributed significantly to the spread of HIV and the rising number of new infections in these states. As India's migrant population grows, research is needed to understand the linkages between migration and HIV in order to design policies to protect migrants and their sexual partners.
THE PROGRESS Population Council researchers conducted landmark studies that examined the contribution of migration to the spread of HIV. One study documented that migrants represent a greater proportion of the HIV-positive than the HIV-negative population, in both home communities and destinations. One-half to three-quarters of HIV infections among both men and women in places with high out-migration could be attributed to circumstances conducive to male out-migration, putting migrants and, subsequently, home communities at risk for HIV. Another study discovered new patterns of sexual behavior among migrants: they were more likely to engage in sex outside marriage than non-migrants; most male migrants initiate sex outside marriage in places of origin, and many continue to engage in such behavior in places of destination. Migrants' sexual networks in places of origin and their unprotected sex with sex workers in places of destination are the mechanisms through which the virus has been spreading.

THE IMPACT This breakthrough in understanding the contribution of migration to the spread of HIV has transformed India's approach toward HIV prevention with migrant populations. The
Council's recommendations have led to the revision of National AIDS Control Program strategy, away from focusing mainly on "hot spots" of migrants only in destination areas, to targeting migrants and their sexual partners at their places of origin, transit, and destination. The Council's study reports and its revised national strategy document on migrants have become trusted resources for donors and public and private institutions throughout India, and form the basis for future initiatives.

DONORS Avahan, the India AIDS Initiative of the Bill and Melinda Gates Foundation, United Nations Development Programme (UNDP) 


\section{DR. TEKLE-AB MEKBIB}

GUIDING ETHIOPIAN POLICY THROUGH

REPRODUCTIVE HEALTH RESEARCH

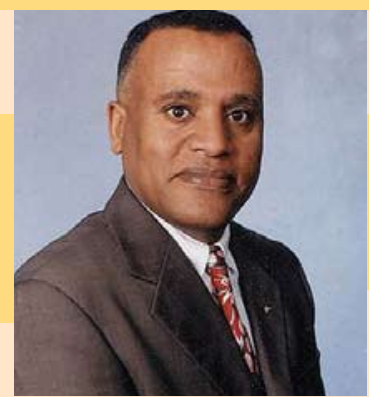

Describe your path to becoming a medical doctor.

During school vacations, I accompanied my sister, a community nurse, when she traveled to rural health centers in Ethiopia. Her team examined children and pregnant women and helped women in labor. I dreamt of becoming a doctor so that I could help women in need. I began my university studies in Addis Ababa. As a result of a national uprising in 1974, the university closed, but I was selected for a scholarship to study medicine in St. Petersburg, Russia and later pursued a PhD there in maternal and neonatal health. In 1988 , I joined the department of obstetrics and gynecology at Yekatit 12 Hospital in Addis Ababa. Becoming a medical doctor and ob-gyn specialist has been the most gratifying event in my life.

How did your career lead you to work with the Population Council?

In 1997, the Ethiopian Ministry of Health conducted a national reproductive health needs assessment to identify gaps and challenges in delivering services. I helped staff from the Council and the World Health Organization as a national expert for this survey. During our collaboration, Council staff influenced me to step out of my day-to-day work and see the big picture. Later, I served as a consultant and medical advisor and coordinated the Council's research to assist the Ministry of Health to expand contraceptive choice throughout Ethiopia.

\section{PROFILE}

\section{DR. WAFAA EL-SADR}

\section{COUNCIL TRUSTEE}

As director of ICAP at Columbia University, Dr. El-Sadr leads a staff of more than 1,100 people who are providing technical assistance to resource-limited countries for HIV prevention, care, and treatment programs. Dr. El-Sadr is also the director of the Center for Infectious Disease Epidemiologic Research and a professor of epidemiology and medicine at Columbia University.

I was well aware of the work of the Population Council long before I became a board member. Through my own work on HIV, I had the opportunity to interact and collaborate with Council staff. In the context of ou shared work, I gained an awareness of the Council's fierce commitment to the issues it addresses and to its mission.

The Council's work is compelling to me because of the links it makes. It conducts high-quality research and translates it into program activities and best practices in ways that can influence policy. I'm also impressed with the breadth of the organization's work. It has a long history and tradition in women's health and a commitment to family planning. It is also a leader in HIV-prevention research while doing cutting-edge work on gender and youth dynamics. Here again, the Council creates links. Its staff collaborates across the key areas of focus for the Council, learning from each other and strategizing in an effort to answer questions in new ways. No other organization brings together such a broad array of issues and approaches.

Since joining the Council's board in 2007 , I've always really looked forward to board meetings and the opportunities to meet with Council staff and leadership. Like

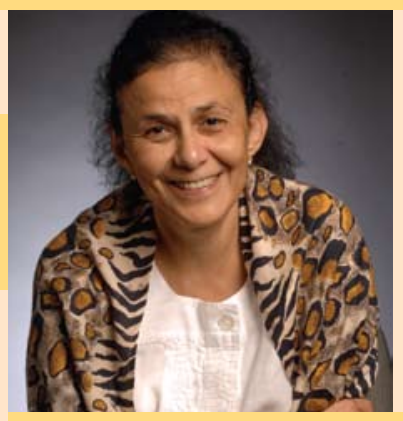

WHY I GIVE TO THE POPULATION COUNCIL

the Council's staff, the board is made up of a diverse group of people hailing from different professional and geographic backgrounds. And like the Council staff, the members of the board have a palpable commitment to the Council's work and a deep appreciation of the very real impact that work makes in the world. It's inspiring to be a part of an engaged team of people who are dedicated to using their unique experience and expertise to moving the Council's mission forward.

Now more than ever, I think it is important to support the work of the Council. There is a perception that some of the issues the Council works on are no longer critical, that we have all the answers and tools we need. This is so far from the reality. The Council continues to work on some of the most critical health issues, such as preventing the spread of HIV in vulnerable populations and meeting the unique needs of girls in poverty. Moreover, the Council continues to seek out and identify new patterns of inequity and need

We find ourselves on the threshold of a new era in public health, due to the abundance of new tools and technological capabilities. Organizations like the

Council, with its depth of history and breadth of expertise, are critical at this point in time for articulating what we know and what we don't know, and therefore where we are going. 


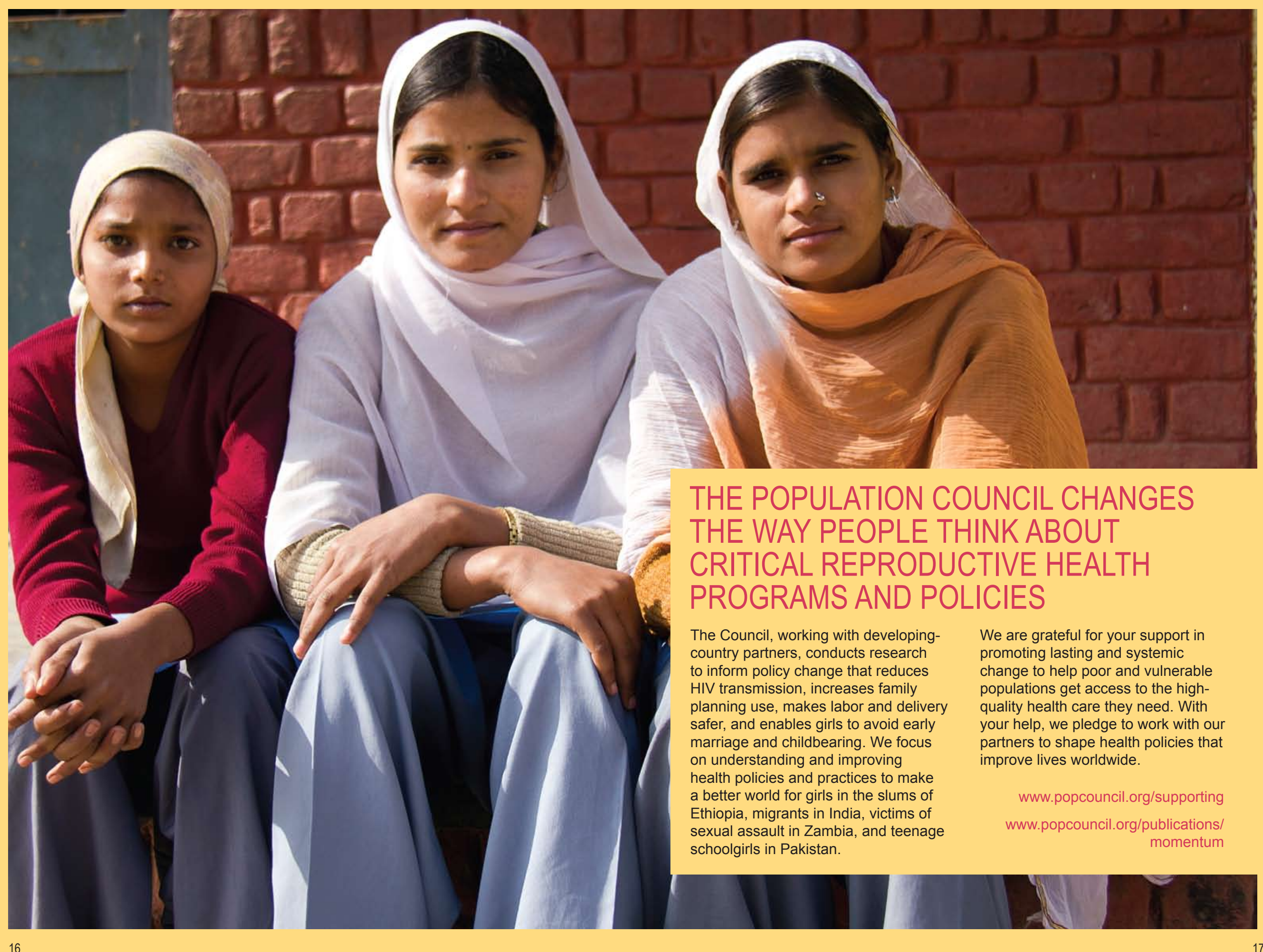



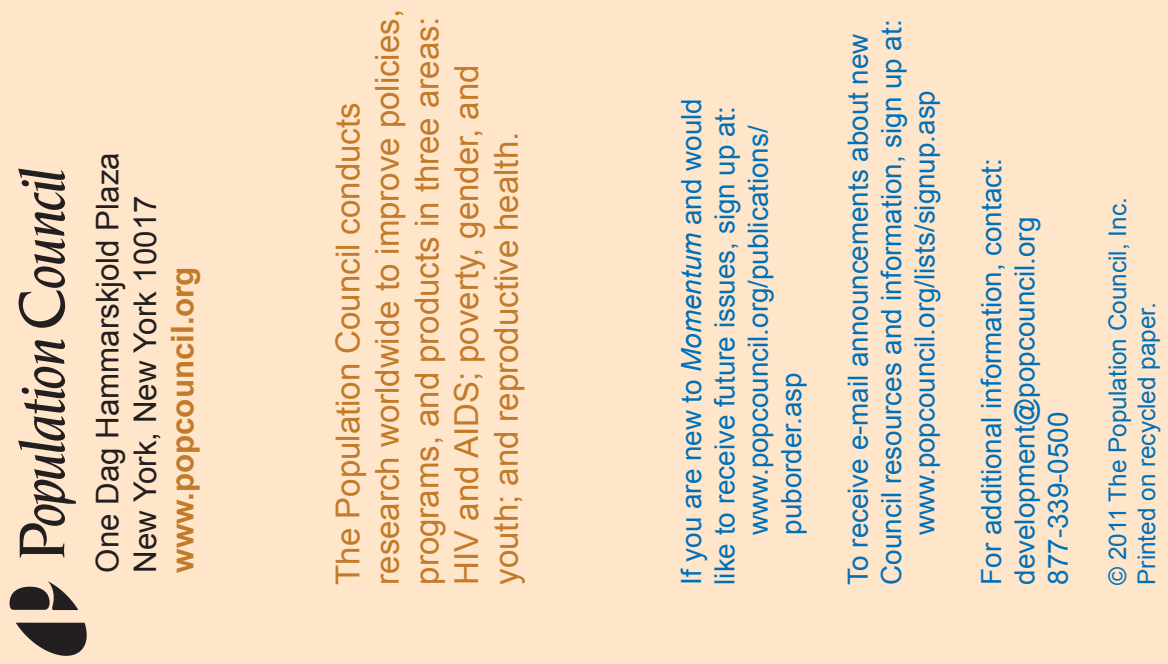